University of South Florida

DIGITAL COMMONS

Digital Commons @ University of

@ UNIVERSITY OF SOUTH FLORIDA

South Florida

March 2020

\title{
A Comparison of Verbal Feedback and Video Feedback to Improve Dance Skills
}

Shreeya Sudhir Deshmukh

University of South Florida

Follow this and additional works at: https://digitalcommons.usf.edu/etd

Part of the Behavioral Disciplines and Activities Commons, and the Social and Behavioral Sciences Commons

\section{Scholar Commons Citation}

Deshmukh, Shreeya Sudhir, "A Comparison of Verbal Feedback and Video Feedback to Improve Dance Skills" (2020). USF Tampa Graduate Theses and Dissertations.

https://digitalcommons.usf.edu/etd/8185

This Thesis is brought to you for free and open access by the USF Graduate Theses and Dissertations at Digital Commons @ University of South Florida. It has been accepted for inclusion in USF Tampa Graduate Theses and Dissertations by an authorized administrator of Digital Commons @ University of South Florida. For more information, please contact digitalcommons@usf.edu. 
A Comparison of Verbal Feedback and Video Feedback to Improve Dance Skills

by

\begin{abstract}
Shreeya Sudhir Deshmukh
A thesis submitted in partial fulfillment

of the requirements for the degree of

Master of Science

Applied Behavior Analysis

Department of Child and Family Studies

College of Behavioral and Community Sciences

University of South Florida
\end{abstract}

Major Professor: Raymond Miltenberger, Ph.D., BCBA-D

Kimberly Crosland, Ph.D., BCBA-D

Mallory Quinn, Ph.D., BCBA-D

Date of Approval:

March 9, 2020

Keywords: video feedback, verbal feedback, dance, sports performance

Copyright (C) 2020, Shreeya Sudhir Deshmukh 


\section{DEDICATION}

I am dedicating my thesis to my family and friends who have supported me through this process. Thank you to my parents and my brother who have encouraged me to pursue my education and my interests. To my best friends, thank you for being there for me. You all helped me stay focused and determined. Thank you, Jay, for being my rock and being patient with me.

I cannot thank you all enough for your unconditional love for me. I love you all so much. 


\section{ACKNOWLEDGEMENTS}

I would like to thank my advisor Dr. Raymond Miltenberger for his advice and guidance over the past two years. I was determined to come to USF and work with you and it has been an amazing experience. I am excited to continue working with you for the next few years.

To Dr. Mallory Quinn, thank you for trusting me to work with your ABA Sports Innovations dancers. You are an inspiration to me as one of the few women working clinically in ABA and sports. I cannot thank you enough for your mentorship as I begin my journey in applied behavior analysis and sports.

Thank you to my data collectors, Rachel Ayres, Alex Capalbo, and Lindsey Snyder who worked with me for months. Best of luck in the future. Thank you to my committee member, Dr. Kimberly Crosland, for her recommendations and participation in my thesis process. Thank you, Butler for pushing me to better throughout these past two years. I cannot wait to see what you do next. 


\section{TABLE OF CONTENTS}

List of Tables ............................................................................................................

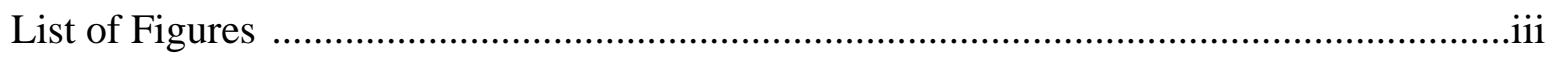

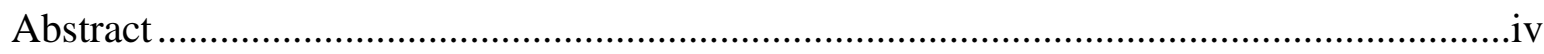

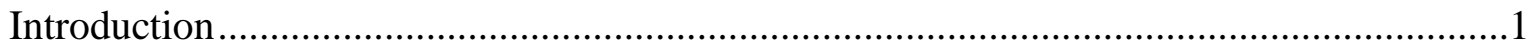



Participants and Setting .............................................................................

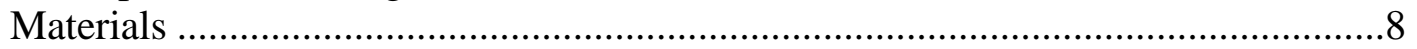

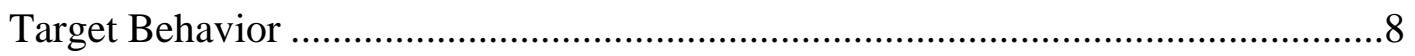

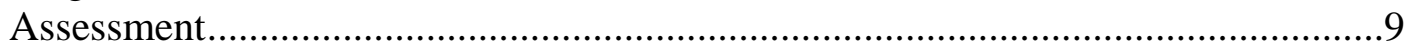

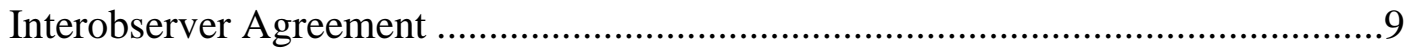





Experimental Design and Procedures .....................................................................12

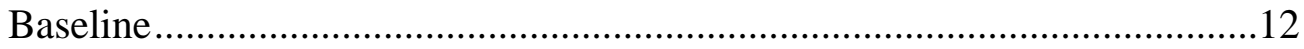

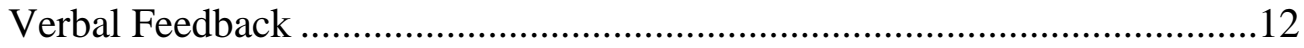

Video Feedback ………………………......................................................13

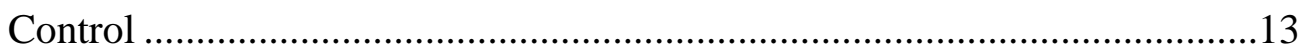

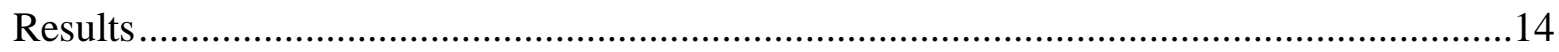



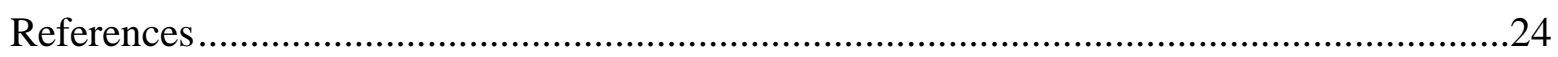

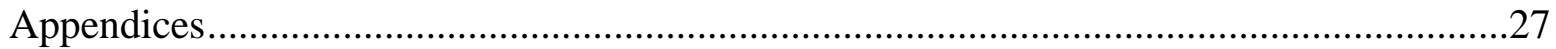

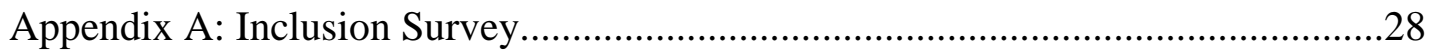

Appendix B: Task Analysis ..................................................................................29

Right Single Pirouette Task Analysis .......................................................29

Right Straddle Leap Task Analysis...............................................................31

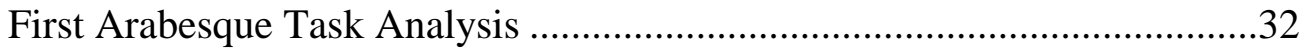

Right Double Pirouette Task Analysis.........................................................34

Needle Task Analysis ..................................................................................

Appendix C: Treatment Integrity Checklists ............................................................38

Appendix D: Social Validity Expert Rating of Videos ……………….....................40

Appendix E: Social Validity Questionnaire...........................................................41

Appendix F: IRB Approval Letter .......................................................................43 


\section{LIST OF TABLES}

Table 1: Scores on Social Validity Questionnaire for Each Participant .............................22 


\section{LIST OF FIGURES}

Figure 1: Results for all participants .............................................................................23 


\begin{abstract}
Research has shown that video feedback and verbal feedback can improve a variety of skills related to several sports. The purpose of this study was to compare the effectiveness of these two forms of feedback for improving dance skills. In this study, the dance skills of three participants were assessed. Verbal feedback and video feedback were implemented using a multiple baseline across participants with an embedded alternating treatments design to allow for a direct comparison of the interventions. The results indicated that verbal feedback was more effective for one participant and video feedback was more effective for one participant. More data is needed for the third participant to determine which intervention was more effective.
\end{abstract}




\section{INTRODUCTION}

In a sports and health poll conducted in the United States of America (Sports and Health in America, 2015), 41\% of parents whose children play sports indicated that their children play year-round, and 58\% of parents said their children play for a specific sports season. The poll showed that $25 \%$ of adults play sports and of those who play sports, $50 \%$ play every day or a few times a week, and $21 \%$ of play once a week. The data indicate that both children and adults are involved in sports for a substantial portion of the year, which suggests the social significance of sports to these individuals.

The effectiveness of feedback-based interventions has been investigated for improving sports performance in many sports, such as gymnastics (Baudry, Leroy, \& Chollet, 2006), golf (Guadagnoli, Holcomb, \& Davis, 2002), volleyball (Barzouka, Bergeles, \& Hatziharistos, 2007), swimming (Dowrick \& Dove, 1980), dance (Fitterling \& Ayllon, 1983), and yoga (Downs, Miltenberger, Biedronski, \& Witherspoon, 2015). Schenk and Miltenberger (2019) identified five feedback-based interventions used in sports research: verbal feedback, video feedback, public posting, self-monitoring, and graphical feedback.

Verbal feedback involves the coach or researcher delivering praise on elements of the skills performed correctly and instructions on elements of the skill to improve. Video feedback involves the coach or researcher showing the participant a video of his or her performance of the skill while providing verbal feedback. Often, these feedback interventions will be combined with other interventions as a package intervention to improve sports skills (e.g., Boyer, Miltenberger, Batsche, \& Fogel, 2009; Emmen, Wesseling, Bootsma, Whiting, \& Van Wieringen, 1985). 
Komaki and Barnett (1977) used a task analysis (TA) to provide verbal instructions and verbal feedback to improve the plays of offensive players on a youth football team. The results suggest that using the TA to provide praise and feedback improved the players' performance of the play due to the precise feedback delivered. Similarly, Kladopoulos and McComas (2001) evaluated a form training intervention, which included instruction and verbal feedback, to improve a basketball foul shot for three female college basketball players. They found that the instructions prior to performing the shot and the verbal feedback about correct elements of the form were effective in improving the form and percentage of shots made by the participants. Although these studies included instructions during intervention, the descriptive verbal feedback also contributed to the success of the interventions.

Video feedback involves the coach or researcher showing a video of the participant's performance in addition to providing verbal feedback about his or her performance. Studies may indicate that the researchers are implementing video feedback alone, but video feedback involves some verbal feedback as part of the intervention.

Bertram, Marteniuk, and Guadagnoli (2007) used a group design to compare verbal feedback and verbal feedback plus video feedback but did not compare video feedback alone. They found that the verbal plus video feedback improved some measures of the golf swing for skilled players, but novice players benefitted from verbal feedback alone. The researchers used a brief, one-day pretest-posttest, rather than repeated measurements of the effects of the intervention over time. Finally, they measured discrete target behaviors (e.g., swing speed, club face, tempo) rather than using a multi-component task analysis.

A single case design can address these limitations by comparing verbal feedback alone and video feedback alone, taking repeated measurements of behavior over time, and using a task 
analysis to measure behavior. An alternating treatments design would allow for a direct comparison of verbal feedback and video feedback without the sequence effects common to other research designs.

Kelley and Miltenberger (2016) found that video feedback was effective in improving the horseback-riding skills of four participants to higher levels than they achieved with verbal feedback from the riding instructor. However, the verbal feedback provided was related to the general performance of the skill which was typical of the lessons prior to the start of the study. Specific verbal feedback based off a TA would be the ideal manner of delivering verbal feedback (Komaki \& Barnett, 1977). Similarly, Stokes, Luiselli, Reed, and Fleming (2010) found that offensive line blocking skills did not improve with verbal feedback alone. Verbal and video feedback improved the skills, but TAGteach (a form of auditory feedback) improved skills even more. These studies illustrate that video feedback produces greater gains in performance than verbal feedback alone.

BenitezSantiago and Miltenberger (2016) evaluated video feedback to improve capoeira skills (a form of martial arts) in a multiple baseline across behaviors design. All participants improved their performance during the video feedback phase and made further improvements during video feedback with extra practice opportunities. This study shows that additional practice opportunities prior to assessment of the skill allows for greater improvements in performance.

However, some studies have found that video feedback did not produce improvements in sports performance (e.g., Emmen et al, 1985; VanWieringen, Emmen, Bootsma, Hoogesteger, \& Whitting, 1989). Van Wiernghen et al. (1989) used a pretest, posttest group design to compare three groups of tennis players performing tennis serves. The traditional training (TT) group 
received sessions involving 30-min training on the tennis serve and 10-min video analysis of expert models. The video feedback (VF) group received sessions involving 30-min training on the tennis serve and 10-min video analysis of video recordings of their serves during the training. The control group did not receive any training and completed a tennis diary. The researchers found that video feedback did not improve the tennis serve of intermediate level players. Van Wiernghen et al. (1989) used a video feedback procedure that was different than the video feedback procedure typically used in behavior analytic research (e.g., BenitezSantiago \& Miltenberger, 2016; Kelley \& Miltenberger, 2016) as the delivery of video feedback was not immediately after the performance of a single tennis serve. The conclusion made by Van Wiernghen et al. (1989) that video feedback did not result in improvements in performance may be a limitation of the procedure used and cannot be generalized to the procedure described in Kelley and Miltenberger (2016) and BenitezSantiago and Miltenberger (2016). The differing results of studies on confirming the effectiveness or ineffectiveness of video feedback requires more investigation.

In recent years, variations of video feedback interventions have been extended to evaluate the effectiveness of the interventions to improve dance skills. Quinn, Narozanick, Miltenberger, Greenberg, and Schenk (2018) evaluated video modeling (VM) alone and a video modeling with video feedback (VMVF) to improve the dance skills of four competitive dancers in a multiple baseline across participants design. In baseline, the dancer was only assessed and did not receive any feedback on his or her performance. During the VM condition, the researcher showed the participant a video of an expert performing the skill. The participant attempted to perform the skill three times watching the video in between each execution of the skill. After VM, the participant performed the skill three times for assessment without modeling or feedback. In the 
VMVF condition, the same procedure for VM was used, but the researcher also recorded the participant performing the skill and showed the participant the video immediately after while providing descriptive praise and corrective feedback on components of the skill performed. After the VMVF session, the participant performed the skills three times for assessment with no modeling or feedback. The researchers found that VM alone resulted in a small effect on the performance of the skills for the four dancers, but VMVF produced larger increases in performance. This study highlights the benefit that VF can provide when an intervention is only producing a small effect.

When implementing feedback, the participant often views the video of his or her performance immediately after performing the skill video (e.g., Kelley \& Miltenberger, 2016). However, Myers and Bloom (2018) used a multiple baseline across participants with an embedded alternating treatments design to evaluate video feedback as an antecedent and consequent intervention. Two dance skills of three female dancers were evaluated; one skill assigned to receive antecedent VF and the other to receive consequent VF. During baseline, the dancer received no video or vocal feedback on her performance. In antecedent VF, the dancer reviewed the video of the skill from the previous attempt of the skill, and then performed the skill. In consequent VF, the dancer performed the skill, and then reviewed the video. All participants improved their performance of the skills during the intervention phase; however, there was little differentiation between the antecedent and consequent conditions. All participants maintained the skills during follow up and generalization probes. The researcher demonstrated that video feedback as an antecedent intervention or a consequent intervention resulted in acquisition of the skill with little difference between the two types of video feedback. 
Some studies support the effectiveness of video feedback and verbal feedback in improving target skills (e.g., Komaki \& Barrnet, 1977; Myers, 2018), but other studies do not support the same conclusion (e.g., Emmen et al., 1985). The differing results suggest the need for more research to be conducted in the area. Because video feedback includes a verbal feedback component, it would be useful to evaluate the effect of viewing the video on the behavior of the participant. Additionally, because verbal feedback is a more efficient intervention than video feedback, it is important to know if verbal feedback is as effective as video feedback. Therefore, the purpose of this study is to compare the effects of verbal feedback and video feedback on improving dance skills. 


\section{METHOD}

\section{Participants and Setting}

Three students enrolled at a local dance studio participated in this study. The studio owner recommended students to participate in the study based on their availability, need for improvement on skills, and age. The students selected to participate were beginner to intermediate level dancers. Alana, 6 years old, had been dancing for 2 years and training in ballet as a recreational dancer. Amy, 9 years old, had been dancing for 7 years and training in ballet as a competitive dancer. Penelope, 12 years old, had been dancing for 7 years and training in tap, ballet, hip hop, lyrical, and musical theater as a recreational dancer. The inclusion criteria were that the participant performed each of the target behaviors at $50 \%$ or fewer correct steps on a TA developed by the researcher, was typically-developing, and was enrolled in dance classes for at least 1 year. The caregiver of each participant signed a consent form prior to the start of the study and the participants provided signed assent. A fourth participant was a 12-year-old advanced competitive dancer who dropped from this study because she performed the target skills above 50\% steps correct. Each participant completed an inclusion survey (see Appendix A) to ensure the motivation to improve her skills was present. All participants indicated their motivation to improve by rating the item "Getting better at dance is important to me" on the survey a 5 (strongly agree). All participants also indicated that they knew the name of the dance skills that were targeted or had attempted the skills during class, making the use of instructions or modeling on how to perform the skills unnecessary.

Research sessions were conducted before or after the participant's scheduled class or as a private dance session. To control for fatigue, the time of data collection (i.e., before or after 
class) remained consistent for each participant throughout the study. The dance studio contained mirrors, a dance floor, and barres on the walls.

\section{Materials}

The participant wore the appropriate dance clothing to participate in the session (e.g., leggings, tights, leotard, jazz shoes). The researcher used a phone and camcorder to record the sessions and a laptop to display the videos.

\section{Target Behavior}

The studio owner selected three topographically different target behaviors (e.g., one turn, one leap, and one kick rather than two turns and a leap) in need of improvement and similar in difficulty for each participant. Each skill was broken into its components (i.e., steps) and operationally defined in a TA. The TAs were developed by the studio owner who had 10 years of teaching experience in dance, a PhD in applied behavior analysis, and multiple published studies in dance research. She had experience developing TAs and ensured the TAs captured all relevant components of the movement. TAs were created for all of the skills in this study, expect for the needle which was created for a previous study and modified for the right side for this study.

Of the tree skills assessed, two skills were selected to receive training based on the data paths that were the most closely aligned to one another and the means for each skill. Similar to Myers and Bloom (2018), the target skill with the lowest percentage score was trained using video feedback (the intervention we believed would be more effective) and the behavior with the second-lowest score was trained using verbal feedback. If two participants had the same target skill selected, one participant received verbal feedback for that skill and the other participant received video feedback for the skill. The third skill was the control and was not targeted with an 
intervention. Data were collected on the control skill during the intervention phase to show that it did not improve while the other skills were targeted with feedback.

The dependent variable was the percentage of steps in the TA performed correctly (see Appendix B). The percentage was calculated by dividing the number of steps performed correctly by the number of steps on the TA and multiplying by 100 . The duration of the feedback sessions was measured using the recorded videos to determine efficiency of the feedback procedures. For example, if both procedures resulted in a similar level of acquisition (i.e. no differentiation in the percentage correct), the feedback procedure that took less time to implement will be the more efficient procedure.

\section{Assessment}

The participant performed each target skill two times for assessment during each research session. Each performance was considered an assessment. The assessment did not involve any feedback before or after the participant performed the skill. If the participant asked questions or attempted to discuss the skill with the researcher, the researcher replied, "Try your best." All assessments were video recorded. Each data point on the graph represented the percentage correct during assessment.

\section{Interobserver Agreement}

Interobserver agreement (IOA) data were collected from video by a second observer (the researcher) in each phase for all participants. IOA was collected for $37 \%$ of assessments for Amy, 38\% of assessments for Penelope, and 36\% of assessments for Alana. For Amy, IOA was $95 \%$ (range of $90 \%$ to $100 \%$ ) for the right straddle leap, $92 \%$ (range of $92 \%$ to $92 \%$ ) for the needle, and $94 \%$ (range of $92 \%$ to $100 \%$ ) for the double pirouette. For Penelope, IOA was $93 \%$ (range of $90 \%$ to $97 \%$ ) for the right straddle leap, $94 \%$ (range of $92 \%$ to $100 \%$ ) for the 
arabesque, and $93 \%$ (range of $90 \%$ to $95 \%$ ) for the single pirouette. For Alana, IOA was 94\% (range of $90 \%$ to $100 \%$ ) for the right straddle leap, $96 \%$ (range of $92 \%$ to $100 \%$ ) for the arabesque, and $94 \%$ (range of $90 \%$ to $100 \%$ ) for the single pirouette.

The researcher used behavioral skills training (BST; Himle, Miltenberger, Gatheridge, \& Flessner, 2004) to train the second observer using the video recording of participants engaging in dance moves. Behavioral skills training involved instructions on how to identify correct and incorrect execution of each step. The researcher modeled collecting data on each step of at least two videos while she discussed the steps being recorded. The observer and researcher practiced data collection. The researcher provided descriptive praise and corrective feedback on all the steps scored by the observer. The primary observer was considered trained in data collection after reaching $90 \%$ or higher agreement with the researcher across three consecutive attempts. Retraining of the primary observer occurred if IOA was below 90\%. Retraining involved an additional BST session and required the observer to reach $90 \%$ or higher agreement with the researcher across three consecutive attempts. Whenever retraining was required, the primary observer scored the session again. IOA was calculated using the data from the re-scored assessment. Retraining occurred two times for one data collector and four times for the second data collector. Retraining was not required for the third data collector.

A point-by-point method was used to calculate IOA in which the number of steps on the TA where the two observers agreed on the occurrence or nonoccurrence of a step was divided by the number of steps on the TA and multiplied by 100 which resulted in a percentage.

\section{Treatment Integrity}

Treatment integrity data were collected for of training sessions and assessments by an observer using a TA checklist (see Appendix C) while observing the researcher's behavior via 
video. For Amy, treatment integrity was $100 \%$ for $34 \%$ of assessments, $95 \%$ for $33 \%$ of verbal feedback sessions, and $100 \%$ for $33 \%$ of video feedback sessions. For Penelope, treatment integrity was $100 \%$ for $36 \%$ of assessments, $100 \%$ for $33 \%$ of verbal feedback sessions, and $100 \%$ for $33 \%$ of video feedback sessions. For Alana, treatment integrity was $100 \%$ for $35 \%$ of assessments, $92 \%$ for $33 \%$ of verbal feedback sessions, and $100 \%$ for $33 \%$ of video feedback sessions.

The observer recorded a "Yes" if the step was implemented correctly by the researcher or a "No" if the step was implemented incorrectly by the researcher. Treatment integrity was calculated by dividing the number of steps performed correctly by the number of steps on the TA and multiplying by 100 to produce a percentage.

The researcher was retrained if treatment integrity was below 90\%. Retraining involved the researcher practicing the session with an observer who was collecting treatment integrity data. The researcher achieved a $90 \%$ or higher across three consecutive attempts to be considered retrained in the protocol. Retraining was not required.

\section{Social Validity}

A dance instructor watched assessment videos of the participants performing the skills from the last two sessions of each phase of the study in random order. The instructor was blind to the phase from which the videos were selected. The instructor rated the performance of the skill on a $1-10$ point scale $(1=$ poor performance, $10=$ expert performance $)$ and was able to write comments (see Appendix D).

Responses to items on a social validity questionnaire (see Appendix E), adapted from Boyer et al. (2009) and Quinn, Miltenberger, and Fogel (2015), were assessed in an interview format to ensure the participants' understanding of the items and correct use of the rating scale. 
The researcher provided examples of using the scale to rate statements by saying statements about the participant's liked and disliked foods and having the participant rate them. The participants rated each of the 12 items using a 5-point scale $(1=$ strongly disagree to $5=$ strongly agree).

\section{Experimental Design and Procedures}

A multiple baseline across participants with an embedded alternating treatments design was used for this study. For Amy and Penelope, only one type of feedback session (i.e., verbal feedback or video feedback) was conducted each day and was followed by assessment of that skill. For Alana, video feedback and verbal feedback sessions were conducted on the same day with a 45-min break in between the two sessions. The performance of the participants during the training session was not scored. Only assessments were scored as it was representative of performance in the extinction conditions in the natural environment (e.g., stage performance, auditions). The dance instructor was not to do any additional rehearsals of the target skills in class than she typically would. The participants were told not to practice the skills outside of research sessions and dance class. The participants could warm up for up to 10 min prior to starting research sessions.

Baseline. In baseline, assessment trials were conducted for three skills in random order. No verbal or video feedback was delivered.

Verbal feedback. The session began with the researcher instructing the participant to perform the target skill. The researcher provided feedback specific to the components of the TA; telling the participant which steps he or she performed correctly and how to improve on steps performed incorrectly. For example, the researcher may say, "Your tendue was turned out beautifully! I liked that your ankles touched during the chasse. Next time hold your landing for 
the full $5 \mathrm{~s}$ without wobbling. Bring your arms into second position when you leap." The participant and researcher did not see the TA during feedback delivery. After giving the participant verbal feedback on her performance, the researcher told the participant to execute the skill again and try to do what the researcher said to do to improve. The researcher then provided verbal feedback based on this performance of the skill in the same manner as described previously. The researcher repeated this process one more time so the participant received feedback on three executions of the skill. The participant then performed the skill two times for assessment with no feedback provided.

Video feedback. The session began with the researcher instructing the participant to perform the target skill and recording the participant performing the skill. Using the features of video technology (e.g., rewind, slow motion, pause), the researcher showed the video to the participant on the laptop and provided descriptive praise on the steps performed correctly and corrective feedback on the steps performed incorrectly. For example, the researcher may pause on elements in the video and say, "In this frame, your tendue is turned out! In the next frame you can see that your ankles touched! Great job! Next time, bring your arms into second position during your leap." The participant and the researcher did not see the TA during the feedback session. The participant executed the skill, watched the video, and received feedback two additional times. The participant received video feedback for three executions of the skill prior to assessments. The participant performed the skill two times for assessment with no feedback.

Control. After verbal feedback and video feedback sessions were conducted, the researcher assessed the control skill. The assessment did not involve any feedback after performance. 


\section{RESULTS}

The results are shown in Figure 1. Verbal feedback was more effective in improving the performance of dance skills of Penelope and video feedback was more effective for Alana. More data must be collected for Amy to determine which intervention was more effective, but both interventions resulted in improvements in performance. End-of-intervention means (i.e., mean of the last six data points or the mean of available data points that were fewer than six) were analyzed to emphasize the improvement of each skill towards the end of training. Researchers focused on these data because performance in sports research typically increases throughout the entire intervention phase (Kelley \& Miltenberger, 2016). Additionally, the separation of the data paths for verbal and video feedback and the patterns in the data were analyzed to compare the effectiveness of the feedback interventions.

Amy's performance of the right straddle leap (verbal feedback) increased from a baseline mean of $31.4 \%$ to an end-of-intervention mean of $70.2 \%$. Amy's performance of the double pirouette (video feedback) increased from a baseline mean of $25.7 \%$ to an end-of-intervention mean of $55.8 \%$. Her performance of the needle (control) remained constant from a baseline mean of $20.0 \%$ to an end-of-intervention mean of $23.3 \%$. The introduction of the feedback interventions resulted in an immediate and similar effect for the double pirouette and the right straddle. The data paths separated in session 18 but came back together by session 21 . Additionally, the performance of the right straddle leap targeted with verbal feedback showed a decreasing trend at the end of the phase. Both interventions resulted in improvements in performance compared to the control; however, more data must be collected to determine which intervention was more effective for Amy. 
Penelope's performance of the arabesque (verbal feedback) increased from a baseline mean of $25.0 \%$ to an end-of-intervention mean of $90.0 \%$. Penelope's performance of the right straddle leap (video feedback) increased from a baseline mean of $18.3 \%$ to an end-ofintervention mean of $49.5 \%$. Her performance of the single pirouette (control) increased slightly from a baseline mean of $9.3 \%$ to an end-of-intervention mean of $20.8 \%$, but four of five data points were in the same range as baseline. The introduction of verbal feedback resulted in an immediate effect for the arabesque with a further increase by the end of the phase. The introduction of video feedback produced a gradual increase in the right straddle leap that stabilized by the end of the phase. Penelope's performance indicated that verbal feedback was more effective for her.

Alana's performance of the right straddle leap (verbal feedback) increased from a baseline mean of $27.8 \%$ to an end-of-intervention mean of $37.8 \%$. Her performance of the arabesque (video feedback) increased from a baseline mean of $27.6 \%$ to an end-of-intervention mean of 58.3\%. Her performance of the single pirouette (control) remained constant from a baseline mean of $8.5 \%$ to an end-of-intervention mean of $9.25 \%$. Video feedback produced an immediate effect in the arabesque and maintained throughout most of the phase except for session 26 in which there was a decrease in performance that increased again in the following sessions. Verbal feedback did not produce an immediate effect as Alana's performance did not result in substantial improvements of the right straddle leap. Her performance indicated that video feedback was more effective for her.

The results of the social validity questionnaire (Table 1) indicated that Penelope and Alana preferred the video feedback procedure more than the verbal feedback procedure as they rated item 4 a score of 4 and 5, respectively. Penelope reported that both procedures will help 
other dancers equally with a score of 4 for both items and that her dancing got better with both procedures with a score of 4 on both items. She rated item 9 a score of 3 indicating that she was neutral when watching herself dance on video. She felt confident in performing her skills for a stage performance as she rated item 12 a score of 4 . Alana reported that she thought video feedback would help other dancers more than verbal feedback as she rated item 5 a score of 3 and item 6 a score of 5 . She scored item 9 a score of 4 indicating that she was comfortable viewing herself dancing on video. She thought her dancing got better with video feedback (score of 5) compared to verbal feedback (score of 4). She rated item 12 a score of 1 indicating that she was not confident in performing the skills for a stage performance. 


\section{DISCUSSION}

The purpose of the study was to compare the effects of verbal and video feedback on improving dance skills. The results of this study show that verbal feedback was more effective for one participant and video feedback was more effective for one participant.

For Amy, both interventions resulted in an immediate effect compared to the control. The end-of-intervention mean indicated that verbal feedback was more effective; however, considering the lack of separation in the data paths, more data should be collected before determining which intervention was more effective. By the conclusion of intervention, Amy reached $70.2 \%$ on the right straddle leap targeted with verbal feedback and $55.8 \%$ on the double pirouette targeted with video feedback which are significant improvements. During video feedback sessions, Amy's body language (e.g., walking away, rolling her eyes, practicing other dance moves) suggested that she was uninterested in viewing the video at times. A social validity interview will be conducted to assess her preference between the feedback interventions. As both interventions resulted in improvements in her performance, future research should consider the preference of the participant when selecting a feedback intervention to improve performance.

Penelope's data suggest that verbal feedback had an immediate effect in improving the arabesque, but video feedback did not produce an immediate effect in the right straddle leap. By the end of intervention, Penelope reached $90.0 \%$ on the arabesque targeted with verbal feedback and $49.5 \%$ on the right straddle leap targeted with video feedback which are substantial differences in performance suggesting that verbal feedback was more effective. An important consideration is difference in the deficits of the dancer for the two skills. During baseline for the arabesque, Penelope was not performing many steps on the TA. She was skipping critical 
preparation steps and landing in a different style. The first session of verbal feedback involved the researcher explaining the preparation and landing that was on the TA, which Penelope immediately engaged in for the following sessions. During baseline for the right straddle leap, Penelope was attempting most of the steps on the TA but performing them incorrectly. The video feedback session involved feedback on elements of technique and posture which are more difficult to correct quickly. Future research in dance should consider using a model or instructions prior to the first session of baseline (Downs et al., 2015) to ensure the dancer has viewed a correct execution of the skill and can attempt the skill according to the components on the TA which will be used for scoring. Additionally, an analysis of the baseline data may show the deficits of the dancer's performance (i.e., not performing steps vs incorrectly performing steps) which would allow researchers to select skills for intervention that similar in difficulty for that participant.

Alana's prolonged baseline was required due to the local trends in the data, which may have been affected by her lessons on conditioning and technique; however, the dance teacher did not target any of skills in this study. Once behavior stabilized, it was clear that repeated assessments with no feedback involved did not result in improvements in performance. Alana's performance immediately improved with the introduction of video feedback. By the end of intervention, Alana reached $37.8 \%$ on the right straddle leap targeted with verbal feedback and $58.8 \%$ on the arabesque targeted with video feedback suggesting that video feedback was more effective then verbal feedback. On the social validity questionnaire, Alana reported that she was comfortable viewing herself on video by rating the item with a score of 4 . Compared to Penelope, Alana was more comfortable with viewing herself and expressed her excitement for being video recorded to the researcher. Therefore, her interest in viewing her videos may have 
produced greater improvements using video feedback compared to improvements of the other participants using video feedback. Future research should consider the participant's interest and comfort in viewing themselves on video.

Due to the physical limitations of each dancer's body (e.g., flexibility), there are steps on the TA that may not be possible for the participant to perform. For example, Penelope and Alana do not have the flexibility to perform a split; therefore, they cannot perform steps $13,14,19$, and 20 on the TA for the right straddle leap. The physical limitations of their bodies resulted in a ceiling effect of $86.6 \%$ (26 steps out of 30 steps), meaning that they could not score higher than $86.6 \%$ on the right straddle leap. During the intervention phase, Penelope performed the right straddle at $49.5 \%$ of steps performed correctly. The $37.1 \%$ gap between her actual performance and the ceiling effect is due to the ineffectiveness of video feedback, not a physical limitation. Therefore, verbal feedback was more effective for Penelope. For Alana, she performed the right straddle leap at $37.8 \%$, meaning that she had a $48.8 \%$ gap in her actual performance and the ceiling effect. This suggests the ineffectiveness of verbal feedback for Alana. Future research should evaluate the TAs and the dancer's abilities prior to baseline to determine if there are any ceiling effects for certain skills.

Although it was unavoidable considering the nature of the research question, a limitation of the experimental design was the implementation of two interventions in an alternating treatments fashion on two different behaviors of a participant. Ideally, in an alternating treatments design we would want to implement the two interventions on the same skill for a participant. However, it would not be possible to evaluate which intervention resulted in improvements in performance if both were applied to the same skill. Therefore, it was necessary 
to target a different skill for each intervention and select the skills that were performed at similar levels in baseline.

A limitation of this study is in the procedural differences between verbal and video feedback. The researcher provided different amounts of feedback during verbal and video feedback sessions. During verbal feedback in which neither the researcher nor the participant views a video of performance, the researcher must rely on memory to provide feedback. Typically, the researcher provided feedback on 5-10 steps on the TA centered around one part of the skill (e.g., starting position, preparation, skill, landing). During video feedback in which the researcher and participant viewed the performance on video, the researcher moved frame-byframe through the entire skill to provide feedback. Typically, the researcher provided feedback on 15-20 steps on the TA. On one occasion, Penelope commented "that's a lot to think about," after receiving video feedback suggesting that the amount of feedback received at once may be a variable that could influence the effectiveness of video feedback. Future research should compare the two feedback procedures while controlling for the number of steps the researcher reviews.

Another limitation of this study was the amount of time it took to upload the video from the phone camera to the laptop, which was up to 3 min; therefore, video feedback was delayed. Kelley and Miltenberger (2016) considered the importance of the immediacy of video feedback when providing video feedback to improve horse-back riding skills. They provided video feedback using the same device for recording which eliminated the need for uploading the video to another device for display. Future research should use a tablet to record and display videos so that uploading the video to another device is not necessary, and the tablet screen is large enough to view the small details in performance. 
This study extended the research of feedback interventions in sports by providing a direct comparison of verbal and video feedback. The results indicated that verbal feedback was more effective for one participant and video feedback was more effective for one participant in improving dance skills. With the mixed results and small number of participants in this study, researchers need to replicate this comparison of verbal and video feedback and evaluate what factors might make which procedure best for which participants. 


\section{Table 1}

Scores on Social Validity Questionnaire for Each Participant

\begin{tabular}{|c|c|c|c|c|c|}
\hline $\begin{array}{l}\text { Item } \\
\#\end{array}$ & Item & Amy & Penelope & Alana & Mean \\
\hline 1. & $\begin{array}{l}\text { I liked the verbal } \\
\text { feedback procedure. }\end{array}$ & 5 & 4 & 4 & 4.3 \\
\hline 2. & $\begin{array}{l}\text { I liked the video feedback } \\
\text { procedure. }\end{array}$ & 3 & 5 & 5 & 4.3 \\
\hline 3. & $\begin{array}{l}\text { I liked the verbal } \\
\text { feedback more than the } \\
\text { video feedback. }\end{array}$ & 5 & 2 & 1 & 2.7 \\
\hline 4. & $\begin{array}{l}\text { I liked the video feedback } \\
\text { more than the verbal } \\
\text { feedback. }\end{array}$ & 1 & 4 & 5 & 3.3 \\
\hline 5. & $\begin{array}{l}\text { I think verbal feedback } \\
\text { will help other dancers. }\end{array}$ & 4 & 4 & 3 & 3.7 \\
\hline 6. & $\begin{array}{l}\text { I think video feedback } \\
\text { will help other dancers. }\end{array}$ & 3 & 4 & 5 & 4 \\
\hline 7. & $\begin{array}{l}\text { I would like my dance } \\
\text { instructor to use verbal } \\
\text { feedback in the future. }\end{array}$ & 5 & 3 & 5 & 4.3 \\
\hline 8. & $\begin{array}{l}\text { I would like my dance } \\
\text { instructor to use video } \\
\text { feedback in the future. }\end{array}$ & 4 & 4 & 5 & 4.3 \\
\hline 9. & $\begin{array}{l}\text { I felt comfortable viewing } \\
\text { myself dancing on video. }\end{array}$ & 5 & 3 & 4 & 4 \\
\hline 10. & $\begin{array}{l}\text { I think my dancing got } \\
\text { better with verbal } \\
\text { feedback. }\end{array}$ & 4 & 4 & 4 & 4 \\
\hline 11. & $\begin{array}{l}\text { I think my dancing got } \\
\text { better with video } \\
\text { feedback. }\end{array}$ & 4 & 4 & 5 & 4.3 \\
\hline 12. & $\begin{array}{l}\text { I feel confident } \\
\text { performing these skills for } \\
\text { a stage performance. }\end{array}$ & 4 & 4 & 1 & 3 \\
\hline
\end{tabular}

Note. Numbers under columns with participant names show the ratings for each item by the participant. The mean is the average rating score for the item across the participants. A 1- to 5point scale was used with $1=$ strongly disagree; $2=$ disagree; $3=$ neutral; $4=$ agree; $5=$ strongly agree. 




Figure 1. Shows data for Amy (top panel), Penelope (middle panel), and Alana (bottom panel). 


\section{REFERENCES}

Barzouka, K., Bergeles, N., \& Hatziharistos, D. (2007). Effect of simultaneous model observation and self-modeling of volleyball skill acquisition. Perceptual and Motor Skills, 104, 32-42. doi: 10.2466/pms.104.1.32-42

Baudry, L., Leroy, D., \& Chollet, D. (2006). The effect of combined self- and expert-modelling on the performance of the double leg circle on the pommel horse. Journal of Sports Sciences, 24, 1055-1063. doi: 10.1080/02640410500432243

BenitezSantiago, A., \& Miltenberger, R. G. (2016). Using video feedback to improve martial arts performance. Behavioral Interventions, 31, 12-27. doi: 10.1002/bin.1424

Bertram, C. P., Marteniuk, R. G., \& Guadagnoli, M. A. (2007). On the use and misuse of video analysis. International Journal of Sports Science \& Coaching, 2, 37-46. doi: $10.1260 / 174795407789705406$

Boyer, E., Miltenberger, R. G., Batsche, C., \& Fogel, V. (2009). Video modeling by experts with video feedback to enhance gymnastics skills. Journal of Applied Behavior Analysis, 42, 855-860. doi: 10.1901/jaba.2009.42-855

Downs, H. E., Miltenberger, R., Biedronski, J., \& Witherspoon, L. (2015). The effects of video self-evaluation on skill acquisition with yoga postures. Journal of Applied Behavior Analysis, 48, 930-935. doi: 10.1002/jaba.248

Dowrick, P. W., \& Dove, C. (1980). The use of self-modeling to improve the swimming performance of spina bifida children. Journal of Applied Behavior Analysis, 13, 51-56. doi: 10.1901/jaba.1980.13-51 
Emmen, H. H., Wesseling, L. G., Bootsma, R. J., Whiting, H. T. A., \& Van Wieringen, P. C. W. (1985). The effect of video-modelling and video-feedback on the learning of the tennis service by novices. Journal of Sports Sciences, 3, 127-138. doi:

$10.1080 / 02640418508729742$

Fitterling, J. M., \& Ayllon, T. (1983). Behavioral coaching in classical ballet enhancing skill development. Behavior Modification, 7, 345-368. doi: 10.1177/01454455830073004

Guadagnoli, M., Holcomb, W., \& Davis, M. (2002). The efficacy of video feedback for learning the golf swing. Journal of Sports Sciences, 20, 615-622. doi:

$10.1080 / 026404102320183176$

Himle, M. B., Miltenberger, R. G., Gatheridge, B. J., \& Flessner, C. A. (2004). An evaluation of two procedures for training skills to prevent gun play in children. Pediatrics, $113,70-77$.

Kelley, H., \& Miltenberger, R. G. (2016). Using video feedback to improve horseback riding skills. Journal of Applied Behavior Analysis, 49, 138-147. doi: 10.1002/jaba.272

Kladopoulos, C. N., \& McComas, J. J. (2001). The effects of form training on foul-shooting performance in members of a women's college basketball team. Journal of Applied Behavior Analysis, 34, 329-332. doi: 10.1123/tsp.12.3.271

Komaki, J., \& Barnett, F. T. (1977). A behavioral approach to coaching football: Improving the play execution of the offensive backfield on a youth football team. Journal of Applied Behavior Analysis, 10, 657-664. doi: 10.1901/jaba.1977.10-657

Myers, K., \& Bloom, S. (2018). Evaluating video feedback as an antecedent or consequent event for improving performance of dance skill (Unpublished manuscript).

Quinn, M. J., Miltenberger, R. G., \& Fogel, V. A. (2015). Using TAGteach to improve the proficiency of dance movements. Journal of Applied Behavior Analysis, 48, 11-24. 
Quinn, M., Narozanick, T., Miltenberger, R., Greenberg, L., \& Schenk, M. (2019). An evaluation of video modeling and video modeling with video feedback to enhance the performance of competitive dancers. Behavioral Interventions. Early view online publication, https://doi.org/10.1002/bin.1691.

Schenk, M. \& Miltenberger, R. (2019). A review of behavioral interventions to enhance sports performance. Behavioral Interventions, 34, 248-279.

Stokes, J. V., Luiselli, J. K., Reed, D. D., \& Fleming, R. K. (2010). Behavioral coaching to improve offensive line blocking skills of high school football athletes. Journal of Applied Behavior Analysis, 43, 463-472. doi: 10.1901/jaba.2010.43-463

Van Wieringen, P. C. W., Emmen, H. H., Bootsma, R. J., Hoogesteger, M., \& Whiting, H. T. A. (1989). The effects of video-feedback on the learning of tennis service by intermediate players. Journal of Sports Sciences, 7, 153-162. doi: 10.1080/02640418908729833 
APPENDICES 


\section{Appendix A: Inclusion Survey}

1= strongly disagree $\quad \begin{aligned} & \text { 4=agree } \\
& \text { Inclusion Survey }\end{aligned}$
\begin{tabular}{|l|l|rrrrr|}
\hline \multicolumn{1}{|c|}{$\mathbf{5}=$ strongly agree } \\
\hline 1. & Getting better at dance is important to me. & $\mathbf{1}$ & $\mathbf{2}$ & $\mathbf{3}$ & $\mathbf{4}$ & $\mathbf{5}$ \\
\hline 2. & I have heard of the dance moves we will be working on. & $\mathbf{1}$ & $\mathbf{2}$ & $\mathbf{3}$ & $\mathbf{4}$ & $\mathbf{5}$ \\
\hline 3. & I have practiced both dance moves at least once in class. & $\mathbf{1}$ & $\mathbf{2}$ & $\mathbf{3}$ & $\mathbf{4}$ & $\mathbf{5}$ \\
\hline 4. & Both dance moves are equally difficult for me. & $\mathbf{1}$ & $\mathbf{2}$ & $\mathbf{3}$ & $\mathbf{4}$ & $\mathbf{5}$ \\
\hline
\end{tabular}




\section{Appendix B: Task Analysis}

Right Single Pirouette Task Analysis

\begin{tabular}{|c|c|c|}
\hline Step \# & Step Label & Description \\
\hline 1 & Prepare Feet & $\begin{array}{l}\text { Feet in parallel } \\
\text { Toes forward, weight evenly distributed, all toes pressing } \\
\text { into floor. }\end{array}$ \\
\hline 2 & Prepare Arms & $\begin{array}{l}\text { Arms en bas } \\
\text { Low rounded, away from the body, not touching the thighs. }\end{array}$ \\
\hline 3 & Prepare Posture & $\begin{array}{l}\text { Back is straight, lifted out of the hips, chest and chin up, eyes } \\
\text { forward. }\end{array}$ \\
\hline 4 & Tendu Feet & $\begin{array}{l}\text { Feet in first tendu (left foot in first, right in tendu). } \\
\text { Left leg must be straight, hip lifted, right foot pointed and } \\
\text { turned out. }\end{array}$ \\
\hline 5 & Tendu Arms & $\begin{array}{l}\text { Arms extend in second. } \\
\text { Palms down, in line with shoulder, fingertips extended. }\end{array}$ \\
\hline 6 & $\begin{array}{l}\text { Prepare Lunge } \\
\text { Alignment }\end{array}$ & $\begin{array}{l}\text { Knee hip and shoulder are all in alignment (shoulder over } \\
\text { hip, hip over knee). }\end{array}$ \\
\hline 7 & Prepare Lunge & $\begin{array}{l}\text { Right leg is back; left knee forward, front knee does not go } \\
\text { over the toes. }\end{array}$ \\
\hline 8 & $\begin{array}{l}\text { Prepare Lunge } \\
\text { Balance }\end{array}$ & All ten toes press into the floor and there is no wobbling. \\
\hline 9 & $\begin{array}{l}\text { Prepare Lunge } \\
\text { Arms }\end{array}$ & $\begin{array}{l}\text { Arms in jazz third (right arm long in front, left extended to } \\
\text { side). } \\
\text { Arms in line with the shoulders, fingertips extended. }\end{array}$ \\
\hline 10 & Passé & $\begin{array}{l}\text { Right leg lifts up into a connected passé (ankle touching } \\
\text { knee) } \\
\text { Sickling the foot would not count as correct. }\end{array}$ \\
\hline 11 & Passé Foot & Toe is pointed during passé. \\
\hline 12 & Hips Square & $\begin{array}{l}\text { Hips are square and one hip is not lifted higher than the } \\
\text { other. }\end{array}$ \\
\hline 13 & Turn 1 & $\begin{array}{l}\text { A full } 360 \text { degree turn is made } \\
\text { (on releve to count) }\end{array}$ \\
\hline 14 & $\begin{array}{l}\text { Head Spot } \\
\text { During Turn } 1\end{array}$ & Head whips with eyes to the front \\
\hline 15 & Passé Turn 1 & $\begin{array}{l}\text { Passé is sustained during turn (ankle must touch knee) } \\
\text { Sickling the foot would not count as correct }\end{array}$ \\
\hline 16 & Arms Turn 1 & $\begin{array}{l}\text { Arms are in first position in front of the chest. Rounded and } \\
\text { not touching. }\end{array}$ \\
\hline 17 & Posture Turn 1 & $\begin{array}{l}\text { Back remains straight and chest open (no hunching or } \\
\text { leaning to one side) }\end{array}$ \\
\hline 18 & Landing Feet & Land with feet parallel (toes forward, feet hip width). \\
\hline 19 & Landing Posture & Back is straight and hips are tucked \\
\hline 20 & Landing Arms & Arms land in en bas \\
\hline 21 & Landing & Landing is sustained to 5 count on video with no wobbling in \\
\hline
\end{tabular}




\begin{tabular}{|l|l|l|}
\hline & Balance & order to be considered correct. \\
\hline
\end{tabular}


Right Straddle Leap Task Analysis

\begin{tabular}{|c|c|c|}
\hline Step \# & Step Label & Description \\
\hline 1 & Prepare Feet & $\begin{array}{c}\text { Feet in first tendu (left foot in first, right in tendu). } \\
\text { Left leg must be straight, hip lifted, right foot pointed and } \\
\text { turned out. }\end{array}$ \\
\hline 2 & Prepare Arms & $\begin{array}{c}\text { Arms in jazz third. } \\
\text { Left arm forward, right to side, arms extended in line with the } \\
\text { shoulders, fingertips extended. }\end{array}$ \\
\hline 3 & Prepare Posture & $\begin{array}{c}\text { Back is straight, lifted out of the hips, chest and chin up, eyes } \\
\text { forward or to the left side. }\end{array}$ \\
\hline 4 & Chasse Prep & Plié with knees not extending over toes and back straight. \\
\hline 5 & Right Foot Chasse & Right foot leads the chasse \\
\hline 6 & Chasse Ankles & Ankles touch in the air \\
\hline 7 & Chasse Toes & Toes are pointed in the air \\
\hline 8 & Chasse Legs & Legs are straight in the air \\
\hline 9 & Left Foot Step & $\begin{array}{l}\text { Left foot steps after the chasse } \\
\text { No more than one step, must step toe ball heel. }\end{array}$ \\
\hline 10 & Brush Degage & Right leg brushes through first position \\
\hline 11 & Toe Brush & Toe is pointed during the brush \\
\hline 12 & $\begin{array}{c}\text { Right Leg Height } \\
1 \\
\end{array}$ & Height is at minimum 45 degrees \\
\hline 13 & $\begin{array}{l}\text { Right Leg Height } \\
2\end{array}$ & Height is between 45 and 90 degrees \\
\hline 14 & $\begin{array}{l}\text { Right Leg Height } \\
3 \\
\end{array}$ & Height is straight at 90 degrees \\
\hline 15 & Right Leg Turnout & Leg is turned out (knee facing up, heel forward). \\
\hline 16 & Right Leg Straight & Leg is straight \\
\hline 17 & Right Leg Foot & Toe is pointed \\
\hline 18 & Left Leg Height 1 & Height is at minimum 45 degrees \\
\hline 19 & Left Leg Height 2 & Height is between 45 and 90 degrees \\
\hline 20 & Left Leg Height 3 & Height is straight at 90 degrees \\
\hline 21 & Left leg Turnout & Leg is turned out (knee facing up, heel forward). \\
\hline 22 & Left Leg Straight & Leg is straight \\
\hline 23 & Left Leg Foot & Toe is Pointed \\
\hline 24 & Hips & Hips are square facing the front during the jump \\
\hline 25 & Arms In Second & $\begin{array}{l}\text { Arms are in second with palms down extending straight from } \\
\text { the shoulders. } \\
\text { No broken wrist }\end{array}$ \\
\hline 26 & Landing Feet & Land in jazz B plus. Left leg behind the right \\
\hline 27 & Landing Plié & Right knee is bent in a plié, knee does not extend over the toe. \\
\hline 28 & Landing Posture & $\begin{array}{c}\text { Back is straight, hips are aligned, chest and chin are up and } \\
\text { forward. }\end{array}$ \\
\hline 29 & Landing Hold & $\begin{array}{c}\text { Landing is held and stabilized for } 5 \text { seconds with no wobbling. } \\
\text { Lifting any toes off the floor or leaning to the side would be } \\
\text { considered incorrect. }\end{array}$ \\
\hline 30 & Arms in Hold & $\begin{array}{c}\text { Arms En Bas } \\
\text { Rounded, fingertips apart, not touching the thighs. }\end{array}$ \\
\hline
\end{tabular}


First Arabesque TA

\begin{tabular}{|c|c|c|}
\hline Step \# & Step Label & Description \\
\hline 1 & Prepare Feet & $\begin{array}{l}\text { Feet in first position } \\
\text { Heels together, toes apart, weight evenly distributed, } \\
\text { all toes pressing into floor. }\end{array}$ \\
\hline 2 & Prepare Posture & $\begin{array}{l}\text { Back is straight, lifted out of the hips, chest and chin } \\
\text { up, eyes forward, ribs closed. }\end{array}$ \\
\hline 3 & Prepare Arms & $\begin{array}{l}\text { Arms in en bas } \\
\text { Rounded, low, away from the body, broken wrist, } \\
\text { fingertips tucked in, hands do not touch the thighs. }\end{array}$ \\
\hline 4 & Bouree Steps & A few quick steps forward on the tip toes on releve. \\
\hline 5 & Bouree Steps Posture & $\begin{array}{l}\text { Back is straight, lifted up out of the hips, eyes and } \\
\text { chin forward. }\end{array}$ \\
\hline 6 & Bourre Steps Arms & Arms remain en bas. \\
\hline 7 & First Position & Feet come through first position \\
\hline 8 & First Position Plie & $\begin{array}{l}\text { Legs plié in first position. } \\
\text { Knees remain over toes, knees track out over second } \\
\text { and third toe and not forward (rolled in). }\end{array}$ \\
\hline 9 & Degage Derriere Leg & $\begin{array}{l}\text { Left leg lengthens straight behind. There is no bend in } \\
\text { the left knee. }\end{array}$ \\
\hline 10 & $\begin{array}{l}\text { Degage Derriere } \\
\text { Posture }\end{array}$ & Back is straight and chest and chin are up. \\
\hline 11 & $\begin{array}{l}\text { Degage Derriere } \\
\text { Rotation }\end{array}$ & Leg is turned out from the hips. \\
\hline 12 & Degage Derriere Hips & $\begin{array}{l}\text { Hips remain square to the right front corner of the } \\
\text { room and do not open to the side. Hips are square and } \\
\text { one is not lifted significantly above the other. }\end{array}$ \\
\hline 13 & $\begin{array}{l}\text { Degage Derriere } \\
\text { Supporting Leg }\end{array}$ & Right leg is straight, and on releve (tip toe) \\
\hline
\end{tabular}




\begin{tabular}{|l|l|l|}
\hline 14 & Toe Pointed & L leg is pointed \\
\hline 15 & Arabesque Height & L leg reaches at least 45 degrees \\
\hline 16 & Arabesque Height & L leg is between 45 and 90 \\
\hline 17 & Arabesque Height & L leg reaches 90 degrees \\
\hline 18 & Arabesque Arms & $\begin{array}{l}\text { Arms are in first arabesque with the right arm up and } \\
\text { the left arm out straight in line with the shoulder }\end{array}$ \\
\hline 19 & Arabesque Arms & $\begin{array}{l}\text { Shoulders are pressed down away from the ears and } \\
\text { arms are straight }\end{array}$ \\
\hline 20 & Arabesque land & Left leg lowers toe ball heel \\
\hline 21 & Controlled landing & $\begin{array}{l}\text { Leg comes down controlled and does not slam on the } \\
\text { ground }\end{array}$ \\
\hline 22 & Finish Position & Left leg closes to first position \\
\hline 23 & Landing Arms & Arms in en bas \\
\hline 24 & Finish Position & Landing is held for 5 counts with no wobbling \\
\hline 25 & Landing Posture & $\begin{array}{l}\text { Back is straight, hips square and lifted, chest and chin } \\
\text { up }\end{array}$ \\
\hline
\end{tabular}


Right Double Pirouette Task Analysis

\begin{tabular}{|c|c|c|}
\hline Step \# & Step Label & Description \\
\hline 1 & Prepare Feet & $\begin{array}{l}\text { Feet in parallel } \\
\text { Toes forward, weight evenly distributed, all toes pressing } \\
\text { into floor. }\end{array}$ \\
\hline 2 & Prepare Arms & $\begin{array}{l}\text { Arms en bas } \\
\text { Low rounded, away from the body, not touching the thighs. }\end{array}$ \\
\hline 3 & Prepare Posture & $\begin{array}{l}\text { Back is straight, lifted out of the hips, chest and chin up, } \\
\text { eyes forward. }\end{array}$ \\
\hline 4 & Tendu Feet & $\begin{array}{l}\text { Feet in first tendu (left foot in first, right in tendu). } \\
\text { Left leg must be straight, hip lifted, right foot pointed and } \\
\text { turned out. }\end{array}$ \\
\hline 5 & Tendu Arms & $\begin{array}{l}\text { Arms extend in second. } \\
\text { Palms down, in line with shoulder, fingertips extended. }\end{array}$ \\
\hline 6 & $\begin{array}{l}\text { Prepare Lunge } \\
\text { Alignment }\end{array}$ & $\begin{array}{l}\text { Knee hip and shoulder are all in alignment (shoulder over } \\
\text { hip, hip over knee). }\end{array}$ \\
\hline 7 & Prepare Lunge & $\begin{array}{l}\text { Right leg is back; left knee forward, front knee does not go } \\
\text { over the toes. }\end{array}$ \\
\hline 8 & Prepare Lunge Balance & All ten toes press into the floor and there is no wobbling. \\
\hline 9 & Prepare Arms & $\begin{array}{l}\text { Arms in jazz third (right arm long in front, left extended to } \\
\text { side). } \\
\text { Arms in line with the shoulders, fingertips extended. }\end{array}$ \\
\hline 10 & Passé & $\begin{array}{l}\text { Right leg lifts up into a connected passé (ankle touching } \\
\text { knee) Sickling the foot would not count as correct. }\end{array}$ \\
\hline 11 & Passé Foot & Toe is pointed during passé. \\
\hline 12 & Hips Square & $\begin{array}{l}\text { Hips are square and one hip is not lifted higher than the } \\
\text { other. }\end{array}$ \\
\hline 13 & Turn 1 & $\begin{array}{l}\text { A full } 360 \text { degree turn is made } \\
\text { (on releve to count) }\end{array}$ \\
\hline 14 & $\begin{array}{l}\text { Head Spot During Turn } \\
1\end{array}$ & Head whips with eyes to the front \\
\hline 15 & Passé Turn 1 & $\begin{array}{l}\text { Passé is sustained during turn (ankle must touch knee) } \\
\text { Sickling the foot would not count as correct }\end{array}$ \\
\hline 16 & Arms Turn 1 & $\begin{array}{l}\text { Arms are in first position in front of the chest. Rounded and } \\
\text { not touching. }\end{array}$ \\
\hline 17 & Posture Turn 1 & $\begin{array}{l}\text { Back remains straight and chest open (no hunching or } \\
\text { leaning to one side) }\end{array}$ \\
\hline 18 & Turn Double & $\begin{array}{l}\text { A second full } 360 \text { degree turn is made } \\
\text { (releve to count) }\end{array}$ \\
\hline 19 & $\begin{array}{l}\text { Head Spot During Turn } \\
2\end{array}$ & Head whips with eyes to the front \\
\hline 20 & Passé Turn 2 & $\begin{array}{l}\text { Passé is sustained during turn (ankle must touch knee) } \\
\text { Sickling the foot would not count as correct }\end{array}$ \\
\hline 21 & Arms Turn 2 & $\begin{array}{l}\text { Arms are in first position in front of the chest. Rounded and } \\
\text { not touching. }\end{array}$ \\
\hline 22 & Posture Turn 2 & $\begin{array}{l}\text { Back remains straight and chest open (no hunching or } \\
\text { leaning to one side) }\end{array}$ \\
\hline 23 & Landing Feet & Land with feet parallel (toes forward, feet hip width). \\
\hline 24 & Landing Posture & Back is straight and hips are tucked \\
\hline
\end{tabular}




\begin{tabular}{|l|l|l|}
\hline 25 & Landing Arms & Arms land in en bas \\
\hline 26 & Landing Balance & $\begin{array}{l}\text { Landing is sustained to } 5 \text { count on video with no wobbling } \\
\text { in order to be considered correct. }\end{array}$ \\
\hline
\end{tabular}


Needle Task Analysis

\begin{tabular}{|c|c|}
\hline Skill Set: Full Back Catch Scorpion Kick/ Needle (right) & Step Name \\
\hline 1) Legs in first position (small "v"). & Prep Legs \\
\hline $\begin{array}{l}\text { 2) Back is straight, lifted out of the hips, chest and chin up, eyes } \\
\text { forward }\end{array}$ & Prep Posture \\
\hline $\begin{array}{l}\text { 3) Arms en bas low, rounded away from the body, not touching } \\
\text { the thighs. }\end{array}$ & Prep Arms \\
\hline $\begin{array}{l}\text { 4) Feet in first tendu. (left foot in first, right in tendu). } \\
\text { Left leg must be straight, right leg pointed and turned out). }\end{array}$ & Tendu Feet \\
\hline $\begin{array}{l}\text { 5) Arms in 90-degree angle. Left arm in front, right to side. } \\
\text { Fingertips extended from the palm (pointed). }\end{array}$ & Tendu Arms \\
\hline 6) Lifted up out of the hips, chest forward, shoulders back. & Tendu Posture \\
\hline $\begin{array}{l}\text { 7) Catch top of right foot at the toes with right hand. } \\
\text { - At least one finger must be touching toes. } \\
\bullet \quad \text { Top of the hand is visible. }\end{array}$ & Catch \\
\hline $\begin{array}{l}\text { 8) Grab outside of the foot with outside hand (R) in backwards } L \\
\text { formation (palm faces in). }\end{array}$ & Grab \\
\hline 9) Hips stay square. & Hips \\
\hline $\begin{array}{l}\text { 10) Move inside hand (L) to meet other hand to toes. } \\
\text { - Other hand reaches over the head. } \\
\text { - At least one finger should be touching the toe. } \\
\text { - } \text { Must keep holding foot with outside hand. } \\
\text { Overlap of hands is okay }\end{array}$ & Move Hands \\
\hline $\begin{array}{l}\text { 11) Pull to half scorpion } \\
\text { • Leg makes } 90 \text {-degree angle between the two legs }\end{array}$ & Pull to Half \\
\hline $\begin{array}{l}\text { 12) Lift knee higher } \\
\text { • Leg is above } 90 \text { degrees but thigh is not yet straight. }\end{array}$ & Knee Higher \\
\hline $\begin{array}{l}\text { 13) Thigh is pulled straight. } \\
\text { • Thigh part of leg only is at } 180 \text { degrees. }\end{array}$ & Thigh Straight \\
\hline $\begin{array}{l}\text { 14) Pull to full needle. } \\
\text { - Both legs at } 180 \text { degrees, perfect line (needle). }\end{array}$ & Pull to Full \\
\hline $\begin{array}{l}\text { 15) Toes pointed during pull. } \\
\text { • Toe must be pointed from step } 7 \text { until now to be } \\
\text { correct. }\end{array}$ & Toes Pointed \\
\hline 16) Tip head back for at least 3 seconds during steps 6 until now. & Head Back \\
\hline $\begin{array}{l}\text { 17) Hold scorpion for } 5 \text { seconds to the teacher count on the video. } \\
\text { - Maintaining leg up during all } 5 \text { seconds. }\end{array}$ & Hold for 5 \\
\hline $\begin{array}{l}\text { 18) Release hand and bring down controlled. } \\
\text { - Leg comes down softly (i.e.: no audible noise). }\end{array}$ & Land \\
\hline
\end{tabular}




\begin{tabular}{|c|c|}
\hline 19) Release leg is straight & Release Leg \\
\hline 20) Toe is pointed when it lowers into tendu. & Release Toe \\
\hline 21) Balance is held without leaning to one side & Balance during Leg Lower \\
\hline 22) Leg closes from a tendu toe, ball, heel, back to first position. & Close Tendu \\
\hline 23) Feet hold a first position (heels together, toes apart). & Feet First \\
\hline $\begin{array}{l}\text { 24) Arms en bas low, rounded away from the body, not touching } \\
\text { the thighs. }\end{array}$ & Maintain Land \\
\hline 25) Holds land position for at least 5 seconds. \\
$\qquad \quad$ Must maintain balance (body erect). \\
\hline
\end{tabular}




\section{Appendix C: Treatment Integrity Checklists}

\section{Treatment Integrity Checklist- Verbal Feedback}

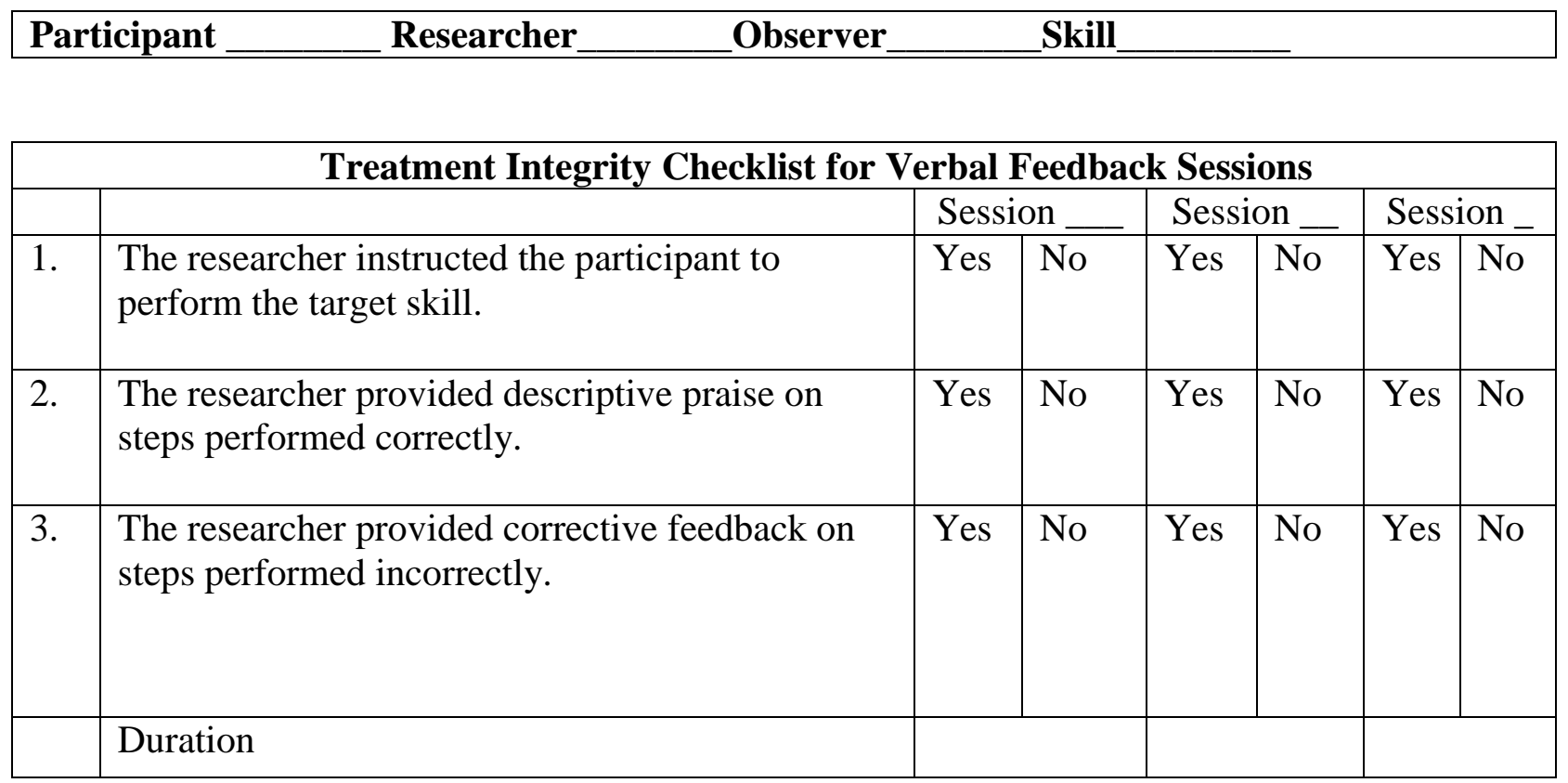

Treatment Integrity Checklist- Video Feedback

\begin{tabular}{|llll|}
\hline Participant __ Researcher___ Observer___ Skill__ \\
\hline
\end{tabular}

\begin{tabular}{|l|l|l|l|l|l|l|l|}
\hline \multicolumn{7}{|c|}{ Treatment Integrity Checklist for Video Feedback Sessions } \\
\hline & \multicolumn{3}{|l|}{ Session } & \multicolumn{2}{|l|}{ Session } & \multicolumn{2}{|c|}{ Session } \\
\hline 1. & $\begin{array}{l}\text { The researcher instructed the participant to } \\
\text { perform the target skill. }\end{array}$ & Yes & No & Yes & No & Yes & No \\
\hline 2. & $\begin{array}{l}\text { The researcher recorded the participant } \\
\text { performing the target skill. }\end{array}$ & Yes & No & Yes & No & Yes & No \\
\hline 3. & $\begin{array}{l}\text { The researcher used features of video } \\
\text { technology (e.g., pause, rewind, slow motion) } \\
\text { to show the participant the performance. }\end{array}$ & Yes & No & Yes & No & Yes & No \\
\hline 4. & $\begin{array}{l}\text { The researcher provided descriptive praise on } \\
\text { steps completed correctly. }\end{array}$ & Yes & No & Yes & No & Yes & No \\
\hline
\end{tabular}




\begin{tabular}{|l|l|l|l|l|l|l|l|}
\hline 5. & $\begin{array}{l}\text { The researcher provided corrective feedback } \\
\text { on steps completed incorrectly. }\end{array}$ & Yes & No & Yes & No & Yes & No \\
\hline Duration & & & & & & \\
\hline
\end{tabular}

\section{Treatment Integrity Checklist- Assessments}

\section{Participant} Researcher Observer Skill

Assessment \#

\section{Treatment Integrity Checklist for Assessments}

\begin{tabular}{|l|l|l|l|}
\hline 1. & The researcher instructed the participant to perform the target skill. & Yes & No \\
\hline 2. & The researcher recorded the participant performing the target skill. & Yes & No \\
\hline 3. & $\begin{array}{l}\text { The researcher did not provide any verbal feedback or video feedback on } \\
\text { performance. }\end{array}$ & Yes & No \\
\hline
\end{tabular}




\section{Appendix D: Social Validity Expert Rating of Videos}

Rater Initials

Scale Used:

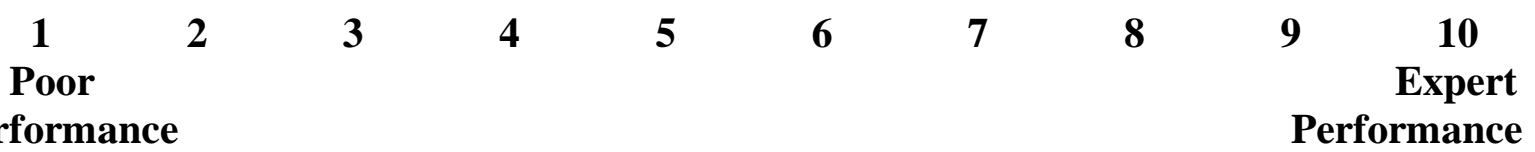

Please rate the performance of the dancers using the 1- to 10- point scale described above. A score of 10 would suggest a perfect, expert-level execution of the skill. A score of 1 would suggest a poor performance of the skill. Scores 2-9 would suggest that some elements of the skill were performed correctly, but with some mistakes. Evaluate each video individually. Do not compare the performance of the dancer to other dancers or to other videos of the same dancer.

\begin{tabular}{|c|c|c|c|c|c|c|c|c|}
\hline \multirow{2}{*}{$\begin{array}{l}\text { Video } \\
\text { Number }\end{array}$} & \multicolumn{7}{|c|}{ Rating (Circle One) } & \multirow[t]{2}{*}{ Comments } \\
\hline & $\begin{array}{c}112 \\
\text { Poor } \\
\text { Performance } \\
\end{array}$ & 4 & 5 & 6 & 7 & 8 & $\begin{array}{lc}9 & 10 \\
& \text { Expert } \\
\text { Performance } \\
\end{array}$ & \\
\hline & $\begin{array}{c}112 \\
\text { Poor } \\
\text { Performance }\end{array}$ & 4 & 5 & 6 & 7 & 8 & $\begin{array}{lc}\mathbf{1 0} \\
\text { Expert } \\
\text { Performance }\end{array}$ & \\
\hline & $\begin{array}{c}1 \\
\text { Poor } \\
\text { Performance }\end{array}$ & 4 & 5 & 6 & 7 & 8 & $\begin{array}{lc}9 & 10 \\
& \text { Expert } \\
\text { Performance }\end{array}$ & \\
\hline & $\begin{array}{c}112 \\
\text { Poor } \\
\text { Performance }\end{array}$ & 4 & 5 & 6 & 7 & 8 & $\begin{array}{lc}9 & 10 \\
& \text { Expert } \\
\text { Performance }\end{array}$ & \\
\hline & $\begin{array}{c}1 \\
\text { Poor } \\
\text { Performance }\end{array}$ & 4 & 5 & 6 & 7 & 8 & $\begin{array}{lc}9 & 10 \\
& \text { Expert } \\
\text { Performance }\end{array}$ & \\
\hline & $\begin{array}{c}112 \\
\text { Poor } \\
\text { Performance }\end{array}$ & 4 & 5 & 6 & 7 & 8 & $\begin{array}{lc}\mathbf{1 0} & \mathbf{E x p e r t} \\
& \text { Expormance }\end{array}$ & \\
\hline & $\begin{array}{c}112 \\
\text { Poor } \\
\text { Performance }\end{array}$ & 4 & 5 & 6 & 7 & 8 & $\begin{array}{lc}\mathbf{1 0} \\
\quad \text { Expert } \\
\text { Performance }\end{array}$ & \\
\hline & $\begin{array}{c}1 \\
\text { Poor } \\
\text { Performance }\end{array}$ & 4 & 5 & 6 & 7 & 8 & $\begin{array}{lc}9 & 10 \\
& \text { Expert } \\
\text { Performance }\end{array}$ & \\
\hline & $\begin{array}{c}112 \\
\text { Poor } \\
\text { Performance }\end{array}$ & 4 & 5 & 6 & 7 & 8 & $\begin{array}{lc}9 & 10 \\
& \text { Expert } \\
\text { Performance }\end{array}$ & \\
\hline
\end{tabular}




\section{Appendix E: Social Validity Questionnaire}

$1=$ strongly disagree

$2=$ disagree $\quad 3=$ neutral $\quad 4=$ agree

$5=$ strongly agree

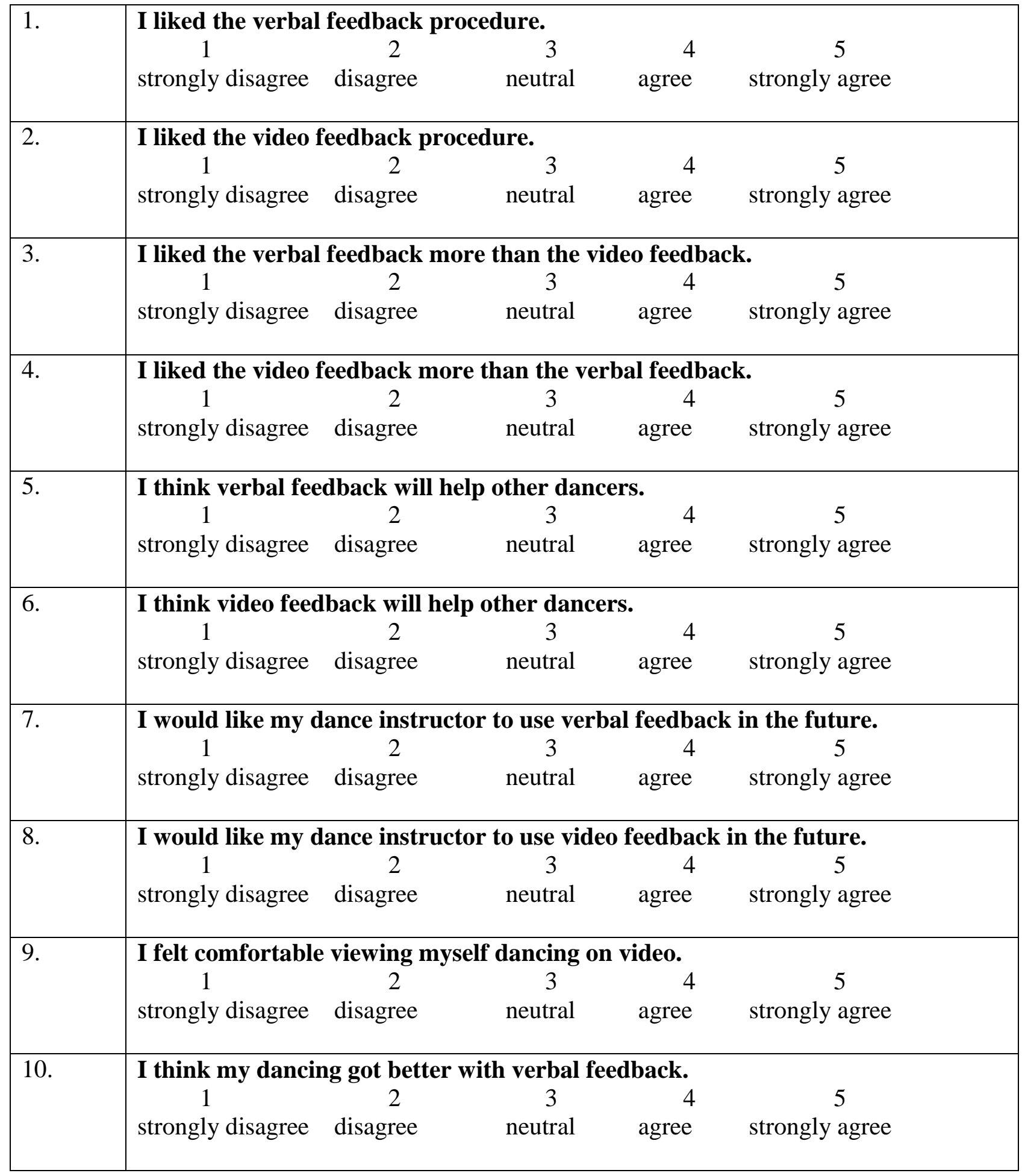




\begin{tabular}{|c|c|c|c|}
\hline 11. & $\begin{array}{ccc}\text { I think my dancing got better with video } \\
1 & 2 & 3 \\
\text { strongly disagree } & \text { disagree } & \text { neutral }\end{array}$ & $\begin{array}{r}\text { ack. } \\
4 \\
\text { agree }\end{array}$ & $\begin{array}{c}5 \\
\text { strongly agree }\end{array}$ \\
\hline 12. & \begin{tabular}{ccc}
\multicolumn{2}{l}{ I feel confident performing these skills for } \\
1 & 2 & 3 \\
strongly disagree & disagree & neutral
\end{tabular} & $\begin{array}{r}\text { age pe } \\
4 \\
\text { agree }\end{array}$ & $\begin{array}{l}\text { mance. } \\
5 \\
\text { strongly agree }\end{array}$ \\
\hline
\end{tabular}




\section{Appendix F: IRB Approval Letter}

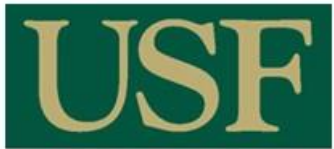

UNIVERSITY OF

SOUTH FLORIDA
RESEARCH INTEGRITY AND COMPLIANCE

Institutional Review Boards, FWA No. 00001669

12901 Bruce B. Downs Blvd., MDC035 • Tampa, FL $33612-4799$

(813) 974.5638 - FAX (813) $974-7091$

July 8,2019

Shreeya Deshmukh

CFBH-Child and Family Behavioral Health Tampa, FL

33612

RE: $\quad$ Expedited Approval for Initial Review

IRB\#: Pro00041064

Title: A Comparison of Verbal Feedback and Video Feedback to Improve Dance Skills

Study Approval Period: 7/8/2019

Dear Ms. Deshmukh:

On 7/8/2019, the Institutional Review Board (IRB) reviewed and APPROVED the above application and all documents contained within, including those outlined below. Please note this study is approved under the 2018 version of 45 CFR 46 and you will be asked to confirm ongoing research annually in place of a full Continuing Review. Amendments and Reportable Events must still be submitted per USF HRPP policy.

Approved Item(s):

Protocol Document(s):

Protocol Version1 6.27.19.docx

Consent/Assent Document(s)*:

Adult Version1 6.30.19.docx.pdf 
Child Written Assent Version1 6.30.19.docx.pdf

Parental Permission Version1 6.29.19.docx.pdf

Child Verbal Assent Version 1 6.27.19.docx

*Please use only the official IRB stamped informed consent/assent document(s) found under the "Attachments" tab. Please note, these consent/assent documents are valid until the consent document is amended and approved. The Child Verbal Assent is not a stamped form.

It was the determination of the IRB that your study qualified for expedited review which includes activities that: (1) present no more than minimal risk to human subjects, and (2) involve only procedures listed in one or more of the categories outlined below. The IRB may review research through the expedited review procedure authorized by 45 CFR 46.110 . The research proposed in this study is categorized under the following expedited review category:

(6) Collection of data from voice, video, digital, or image recordings made for research purposes.

(7) Research on individual or group characteristics or behavior (including, but not limited to, research on perception, cognition, motivation, identity, language, communication, cultural beliefs or practices, and social behavior) or research employing survey, interview, oral history, focus group, program evaluation, human factors evaluation, or quality assurance methodologies.

This research involving children as participants was approved under 45 CFR 46.404: Research not involving greater than minimal risk to children is presented.

Requirements for Assent and/or Permission by Parents or Guardians: 45 CFR 46.408 Permission of one parent is sufficient.

Assent is required of all children.

As the principal investigator of this study, it is your responsibility to conduct this study in accordance with IRB policies and procedures and as approved by the IRB. Any changes to the approved research must be submitted to the IRB via an Amendment for review and approval. Additionally, all unanticipated problems must be reported to the USF IRB within five (5) business days. 
We appreciate your dedication to the ethical conduct of human subjects research at the University of South Florida and your continued commitment to human research protections. If you have any questions regarding this matter, please call 813-974-5638.

Sincerely,
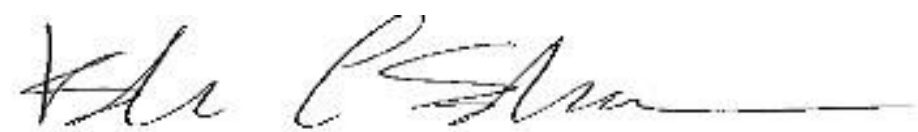

Kristen Salomon, Ph.D., Chairperson

USF Institutional Review Board 